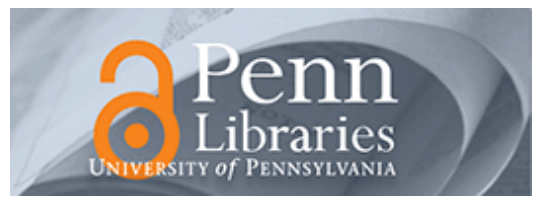

University of Pennsylvania

ScholarlyCommons

Finance Papers

Wharton Faculty Research

\title{
$2-2011$
}

\section{Determinants and Outcomes of Internet Banking Adoption}

Mei Xue

Lorin M. Hitt

University of Pennsylvania

Pei-yu Chen

Follow this and additional works at: https://repository.upenn.edu/fnce_papers

Part of the Business Administration, Management, and Operations Commons, and the Finance and Financial Management Commons

Recommended Citation

Xue, M., Hitt, L. M., \& Chen, P. (2011). Determinants and Outcomes of Internet Banking Adoption.

Management Science, 57 (2), 291-307. http://dx.doi.org/10.1287/mnsc.1100.1187

This paper is posted at ScholarlyCommons. https://repository.upenn.edu/fnce_papers/108

For more information, please contact repository@pobox.upenn.edu. 


\title{
Determinants and Outcomes of Internet Banking Adoption
}

\begin{abstract}
This paper examines the drivers of adoption of Internet banking and the linkages among adoption drivers and outcomes (product acquisition, service activity, profitability, loyalty). We relate Internet banking adoption to customer demand for banking services, the availability of alternative channels, customers' efficiency in service coproduction ("customer efficiency"), and local Internet banking penetration. We find that customers who have greater transaction demand and higher efficiency, and reside in areas with a greater density of online banking adopters, are faster to adopt online banking after controlling for time, regional, and individual characteristics. Consistent with prior work, we find that customers significantly increase their banking activity, acquire more products, and perform more transactions. These changes in behavior are not associated with short-run increases in customer profitability, but customers who adopt online banking have a lower propensity to leave the bank. Building on these observations we also find that the adoption drivers are linked to the postadoption changes in behavior or profitability. Customers who live in areas with a high branch density or high Internet banking penetration increase their product acquisition and transaction activity more than Internet banking adopters in other regions. Efficient customers and those with high service demand show greater postadoption profitability.
\end{abstract}

\section{Keywords}

Internet banking adoption, customer efficiency, network effects

Disciplines

Business Administration, Management, and Operations | Finance and Financial Management 


\title{
The Determinants and Outcomes of Internet Banking Adoption
}

\author{
Mei Xue (xueme@bc.edu) \\ Lorin M. Hitt (lhitt@wharton.upenn.edu) \\ Pei-yu Chen (pychen@temple.edu)
}

\begin{abstract}
This paper examines 1) the drivers of adoption of Internet banking 2) the impact of Internet banking adoption on product acquisition, service activity, profitability and loyalty, and 3) the linkages between adoption and outcome. We relate online banking adoption to customer demand for banking services, the availability of alternative channels, customers' efficiency in service coproduction (“customer efficiency”), and local Internet banking penetration. We find that customers who have greater transaction demand, higher efficiency, and reside in areas with a greater density of online banking adopters are faster to adopt online banking after controlling for time, regional, and individual characteristics. Following adoption, customers significantly increase their banking activity, acquire more products from the bank, and perform more transactions across channels. Consequently, in the short run, online banking adoption is not found to be associated with improved customer profitability. However, it is shown to be associated with stronger customer loyalty. Our exploration of the linkages between online
\end{abstract}


banking adoption and outcome also reveals that the factors influential on adoption in our framework (service demand, customer efficiency, alternative channel access and local penetration) are associated with differences in the post adoption customer profit and profit-related behavior changes.

Keywords: Internet banking adoption, customer efficiency, local penetration effects 